\title{
MENGIDENTIFIKASI MASALAH DALAM DIAGNOSA KEPERAWATAN PADA PASIEN YANG MENDERITA DIABETES MELLITUS
}

\author{
SRI HARVITA SARI MARPAUNG / 181101125
}

$\underline{\text { Sriharvitaaasm11@gmail.com }}$

\begin{abstract}
ABSTRAK
Latar belakang : Diabetes merupakan salah satu penyakit yang penderitanya paling banyak, ini dikarenakan banyaknya faktor yang dapat menimbulkan penyakit DM pada orang yang akan menderitanya. Diagnosa keperawatan merupakan suatu hal yang penting dilakukan pada pasien DM untuk menentukan masalah yang dialami oleh pasien. Tujuan : diharapkan dari penulisan ini adalah dapat menetapkan diagnosa keperawatan kepada pasien yang menderita diabetes mellitus. Metode : menggunakan literature riview berdasarkan teks book, jurnal, e-book (10 tahun terakhir) dengan cara menganalisis, eksplorasi sumber dan kajian bebas. Hasil : dapat memberikan informasi mengenai pengidentifikasian masalah dalam diagnosa keperawatan pada pasien diabetes mellitus sehingga mahasiswa/ perawat mampu menetapkan diagnosis keperawatan pada pasien diabetes mellitus berdasarkan data awal/pengkajian yang dilakukan kepada pasien sehingga dapat melakukan perencanaan keperawatan. Pembahasan : pengertian diabetes mellitus, pengertian diagnosa keperawatan, masalah yang sering dijumpai pada pasien diabetes mellitus. Kesimpulan : diagnosa keperawatan merupakan hal penting yang dilakukan kepada pasien dimana tujuannya adalah untuk mengetahui masalah apa yang diderita oleh pasien sehingga pada saat penanganan perawatan yang diberikan adalah perawatan yang tepat. Salah satunya adalah pada pasien yang menderita diabetes mellitus sehingga derajat kesehatan pasien DM dapat ditingkatkan.
\end{abstract}

Kata kunci : diabetes mellitus, diagnosa keperawatan, masalah pada pasien penderita diabetes mellitus.

\section{LATAR BELAKANG}

Diabetes melitus (DM) merupakan suatu penyakit dimana terjadi gangguan metabolisme karbohidrat, protein dan lemak. Hal ini diakibatkan oleh kurangnya sensitivitas otot ataupun jaringan terhadap insulin, yang disebut dengan resistensi insulin ataupun oleh kurangnya hormon insulin atau disebut dengan defisiensi insulin (Guyton \& Hall, 2007). Diabetes mellitus adalah suatu kumpulan gejala yang timbul pada seseorang disebabkan oleh adanya peningkatan kadar gula glukosa darah akibat kekurangan insulin baik absolut maupun relatif (Syahbudin, 2009). Bahaya diabetes sangat besar dan dapat memungkinkan penderita menjadi lemah ginjal, buta, menderita penyakit 
bagian kaki dan banyak komplikasi serius dan menyebabkan tingkat kematian yang tinggi. Penderita DM menghadapi bahaya setiap harinya karena kadar gula darah yang tidak terkontrol. Glukosa darah mengandung kadar yang berubah-ubah sepanjang hari terutama pada saat makan, dan beraktifitas (Pangestu, 2007).

Dalam beberapa kasus pasien penderita DM di berbagai rumah sakit yang ada, jumlah penderita diabetes merupakan salah satu yang tertinggi penderitanya. Ini disebabkan karena banyak faktor yang dapat menyebabkan timbulnya penyakit diabetes mellitus. Oleh sebab itu, dalam proses keperawatan diagnosa keperawatan merupakan suatu hal yang penting untuk menetapkan masalah yang diderita oleh pasien sehingga dalam memberikan asuhan keperawatan perawat mampu menyesuaikannya dengan masalah yang diderita oleh pasien DM tersebut.

\section{TUJUAN}

Tujuan yang diharapkan dari penulisan ini adalah dapat menetapkan diagnosa keperawatan kepada pasien yang menderita diabetes mellitus.

\section{METODE}

Metode yang digunakan dalam penulisan ini menggunakan literature riview berdasarkan teks book, jurnal, $e$ book (10 tahun terakhir) dengan cara menganalisis, eksplorasi sumber dan kajian bebas.

\section{HASIL}

Hasil yang akan dicapai dari penulisan ini adalah dapat memberikan informasi mengenai pengidentifikasian masalah dalam diagnosa keperawatan pada pasien diabetes mellitus sehingga mahasiswa/ perawat mampu menetapkan diagnosis keperawatan pada pasien diabetes mellitus berdasarkan data awal/pengkajian yang dilakukan kepada pasien sehingga dapat melakukan perencanaan keperawatan.

\section{PEMBAHASAN}

Diagnosa keperawatan merupakan keputusan klinik tentang respon individu, keluarga dan masyarakat tentang masalah kesehatan aktual atau potensial, dimana berdasarkan pendidikan dan pengalamannya, perawat secara akuntabilitas dapat mengidentifikasi dan memberikan intervensi secara pasti untuk menjaga, menurunkan, membatasi, mencegah dan 
merubah status kesehatan klien

(Herdman, 2012). Diagnosa

keperawatan merupakan suatu bagian integral dari suatu proses keperawatan. Hal ini merupakan komponen dari langkah - langkah analisa, dimana perawat melakukan identifikasi terhadap respon-respon individu terhadap masalah-masalah kesehatan yang aktual dan potensial. Dibeberapa negara diagnosa diidentifikasikan dalam tindakan praktik keperawatan sebagai suatu tanggung jawab legal dari perawat yang professional. Diagnosa keperawatan memberikan dasar petunjuk untuk memberikan terapi yang pasti di mana perawat yang bertanggung jawab di dalamnya (Kim, 1984). Diagnosa keperawatan di tetapkan berdasarkan analisis dan interprestasi data yang di peroleh dari pengkajian klien. Diagnosa keperawatan memberikan gambaran tentang kesehatan yang nyata (aktual) dan kemungkinan akan terjadi, dimana pengambilan keputusannya dapat di lakukan dalam batas wewenang perawat.

Diabetes mellitus merupakan suatu penyakit yang dikaitkan dengan penyakit akibat adanya gangguan metabolisme yang ditandai dengan naiknya kadar gula darah akibat kerusakan saat memproduksi insulin. Menurut WHO (World Health Organization), diabetes merupakan penyakit kronis, yang terjadi akibat pankreas tidak menghasilkan insulin yang adekuat, atau ketika tubuh tidak dapat secara efektif menggunakan insulin yang diproduksinya. Hal ini mengakibatkan terjadinya peningkatan konsentrasi glukosa dalam darah yang dikenal dengan istilah hiperglikemia.

Diagnosa yang akan sering dijumpai pada pasien diabetes mellitus adalah sebagai berikut :

a. Ketidakseimbangan nutrisi akibat tidak terpenuhinya nutrisi sesuai dengan kebutuhan dapat dilihat dari gangguan produksi insulin, makan dan pola aktivitas yang dapat dilakukan oleh pasien yang menderita diabetes mellitus.

b. Resiko ketidakstabilan kadar gula darah dikarenakan kurangnya pengetahuan mengenai manajemen diet diabetes.

c. Resiko kekurangan volume cairan dikarenakan diuresis osmotik.

d. Keletihan/kelelahan yang dirasakan oleh pasien saat melakukan aktivitas dikarenakan proses metabolisme untuk menghasilkan energi terasa berat karena peningkatan kadar gula darah. 
e. Kerusakan jaringan/nekrosis jaringan.

f. Resiko infeksi dikarenakan trauma pada jaringan (proses penyakit diabetes mellitus).

g. Ansietas/kecemasan yang dirasakan pasien akibat kurangnya pengetahuan tentang penyakit yang dideritanya.

h. Nyeri akut dikarenakan kerusakan jaringan akibat hipoksia perifer.

Diagnosa yang dapat diambil ataupun diputuskan oleh perawat harus sesuai dengan data di awal pengkajian yang dilakukan pada pasien sehingga pada saat melakukan perencanaan keperawatan dapat disesuaikan dengan masalah yang dialami oleh pasien, sehingga perawatan yang diberikan adalah pelayanan yang berkualitas yang dapat meningkatkan derajat kesehatan pasien.

\section{KESIMPULAN}

Dalam proses keperawatan, diagnosa keperawatan merupakan hal penting yang dilakukan kepada pasien dimana tujuannya adalah untuk mengetahui masalah apa yang diderita oleh pasien sehingga pada saat penanganan perawatan yang diberikan adalah perawatan yang tepat. Salah satunya adalah pada pasien yang menderita diabetes mellitus yang DM tersebut diakibatkan karena ketidakseimbangan nutrisi maka penangan yang diberikan dapat disesuaikan dengan akar masalah yang diderita oleh pasien sehingga kesehatan pasien dapat ditingkatkan.

\section{REFERENSI}

Arjatmo. (2002). Penatalaksanaan

Diabetes Mellitus Terpadu Cetakan 2.

Jakarta : Balai Penerbit FKUI.

Black, J. M. (2014). Keperawatan Medikal Bedah. Indonesia : CV Pentasada Media Eduksi.

Bare \& suzanne. (2002). Buku Ajar Keperawatan Medikal Bedah Edisi 8. Jakarta : EGC.

Corwin,. J . Elizabeth. (2001).

Patofisiologi. Jakarta : EGC.

Gibson, J. (2003). Anatomi dan Patofisiologi Modern untuk Perawat. Jakarta : EGC.

Hincliff. (1999). Kamus Keperawatan. Jakarta : EGC.

Jauhar, M. (2013). Asuhan Keperawatan. Jakarta : Prestasi Pustaka

Mubarak, W. I., Indrawati, L., Susanto, J. (2015). Buku Ajar Ilmu Keperawatan Dasar. Jakarta : Salemba Medika.

Nurarif, A. H. (2015). Aplikasi Asuhan Keperawatan Berdasarkan Diagnosa Medis dan NANDA NIC - NOC. Yogyakarta : Media Action. 
Potter \& Perry. (2010). Fundamental of Nursing (fundamental Keperawatan).

Buku 1. Edisi 7. Indonesia : Salemba Medika.

Potter \& Perry. (2010). Fundamental of Nursing (fundamental Keperawatan).

Buku 3. Edisi 7. Indonesia : Salemba Medika.

Soegondo, S. Dkk. (2007). Penatalaksanaan Diabetes Mellitus Terpadu Cetakan 6. Jakarta : Balai Penerbit FKUI.

Wilkinson, J. M.(2013). Diagnosa Keperawatan Edisi 9. Jakarta : EGC.

Wilkinson, J. M.(2017). Diagnosa Keperawatan Edisi 10. Jakarta : EGC. 